\title{
Persistent organochlorine pesticide residues in freshwater systems and sediments from the Eastern Cape, South Africa
}

\author{
RO Awofolu ${ }^{1}$ and OS Fatoki $\mathbf{i}^{\star}$ \\ ${ }^{1}$ Department of Chemistry, University of Fort Hare, Alice 5700, South Africa \\ ${ }^{2}$ Research \& Development Office, University of Venda for Science \& Technology, P/Bag x5050, Thohoyandou 0950, South Africa
}

\begin{abstract}
Persistent organochlorines such as $\Sigma \mathrm{DDT}$, chlordane, hexachlorobenzene (HCB), heptachlor and endosulfan were determined in water and sediment samples of freshwater systems in the Eastern Cape Province of South Africa that receive runoff from agricultural lands and effluents from industries. The organochlorine pesticides (OCPs) in water and sediments were determined by liquid/liquid extraction and Soxhlet extraction methods, respectively. Percentage recoveries ranged from $71.03 \pm 8.15 \%$ (dieldrin) to $101.25 \pm 2.17 \%(\alpha-\mathrm{BHC})$ in water and from $88.22 \pm 7.85 \%$ (endrin) to $109.63 \pm 5.10$ ( $\beta$-BHC) in sediment. The OCP levels ranged from trace $\left(2,4^{\prime}-\mathrm{DDD}\right)$ to $450 \pm 0.0002 \mathrm{ng} / \ell$ ( $\beta$-BHC) in water samples and from trace (aldrin and 2,4'-DDD) to $184 \times 10^{3} \pm 0.7 \mathrm{ng} / \mathrm{kg}(\beta-\mathrm{BHC})$ in sediments for triplicate analyses. Some endocrinedisrupting OCPs such as $2,4^{\prime}$-DDT, 4,4'-DDT, 2,4'-DDE, heptachlor, endosulfan and the chlordanes were detected.
\end{abstract}

Keywords: organochlorine pesticides, water, sediments, GC-ECD

\section{Introduction}

The presence of organochlorine pesticides (OCPs) in the environment has been of great concern due to their persistent nature and chronic adverse effect on wildlife and humans. Despite the ban and restriction on the usage of OCPs in developed countries during the 1970s and 1980s, some developed countries are still using them for agricultural and public purposes because of their effectiveness in controlling various insects (Tanabe et al., 1994). The early spectacular success of dichlorodiphenyl-trichloroethane (DDT) for malaria control in some countries has seen the continuous use of this insecticide in developing countries. Studies have suggested that these compounds may affect the normal function of the endocrine system (Hileman, 1994). The ability of the prevalent isomer of the major and most persistent DDT derivative, 2,4'-dichlorodiphenyldichloro-ethylene (2,4'-DDE), to bind to the androgen receptor in male rats has been reported (Keice et al.,1995). OCPs have also been linked to human breast and liver cancers and to testicular tumors and lower sperm counts in humans (Davies and Barlow, 1995; Cocco et al., 1997).

The appearance ofDDT and its metabolites in human tissues and its effect on wildlife (USEPA, 1975) triggered its determination in food (Doong and Lee, 1999), water (London et al., 2000) and human milk (Okonkwo et al., 1999). OCP residues have also been found in sediment (Naude et al., 1998) and wildlife (Heath and Claessen, 1999) at significant concentrations.

Water monitoring for OCPs in South Africa (Weaver, 1993; Grobler, 1994; Naude et al., 1998; London et al., 2000), developed European (Fernandez-Alba et al., 1998), Asian (Iwata et al., 1994) and American (Dorothea and Muir, 1991) countries, has shown a widespread occurrence of residues of these pesticides in environmental water systems, though they have been banned for decades. In

\footnotetext{
* To whom all correspondence should be addressed. 푱+2715962 8504; fax: +2715962 8493; e-mail: Fatoki@univen.ac.za Received 29 July 2002; accepted in revised form 3 March 2003.
}

developing countries such as South Africa, this group of chemicals is still used in agriculture, and it is believed to still be in use clandestinely under unknown trade names, due to their low cost. DDT is still used officially in malaria areas for malaria vector control applied by the Department of Health and Welfare. However, there is still a paucity of data on OCP residues in the South African water environment.

Liquid/liquid extraction(LLE) is a common method used for the determination of organic pollutants in water (USEPA, 1984; Tan, 1992; Hernandez et al., 1993; Powell, 1995). The study by Tan (1992) has shown this method as more reliable than solid phase extraction. The use of commercial solid phase extraction cartridges during sample preparation has been shown to render interferences, especially when gas chromatography-electron capture detection is used for analysis. Extraneous peaks, which appear in the gas chromatograms, have been attributed to phthalate esters contained in the housing materials of these cartridges. The liquid/liquid extraction method was evaluated in this study using 15 OCPs in water from freshwater sources using dichloromethane (DCM) as solvent. This study indicated that the liquid/liquid extraction method for sample enrichment of OCPs in the environmental water samples would render to more reliable data.

Soxhlet extraction (SE) is an established technique that has been used for the extraction of organic pollutants from marine sediment and soil samples (USEPA, 1990; Snyder et al., 1992). In this study, a Soxhlet extraction method for the determination of 15 OCPs in sediment was evaluated.

The methods - liquid/liquid extraction and Soxhlet extraction were applied to monitor for OCP residues in freshwater systems. The study areas selected were the Buffalo, Keiskammahoek, Tyume and Swartkops Rivers as well as the Sandile Dam, in the Eastern Cape Province of South Africa.

The objectives of this work were to use the liquid/liquid extraction and Soxhlet extraction methods that would be evaluated to determine the levels of OCPs in freshwater and sediment from the Eastern Cape and to assess whether the levels detected in water and sediment pose cause for concern. 


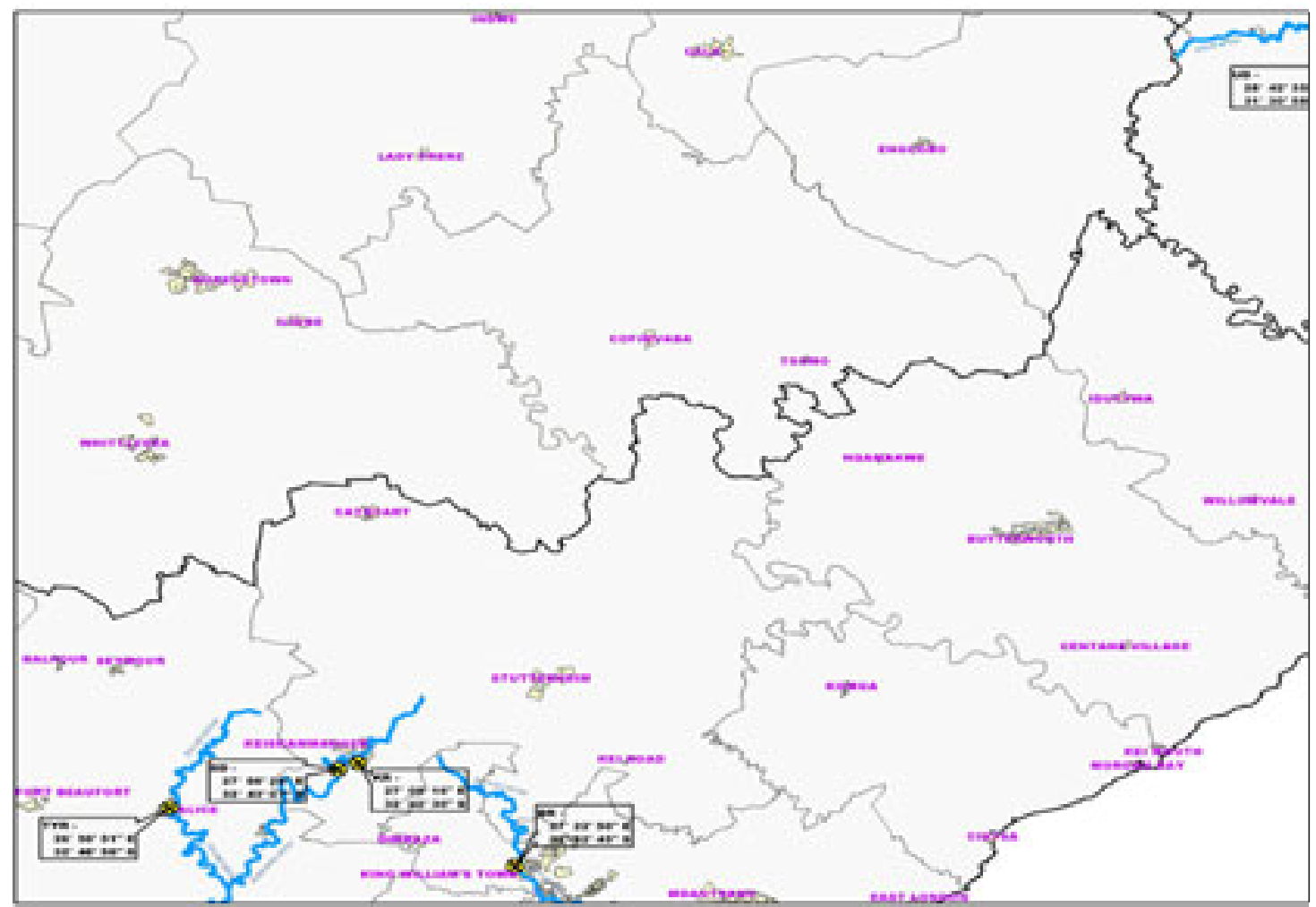

Figure 1

Map of the sample sites.

$B R=$ Buffalo River, $K R=$ Keiskamma River, $S D=$ Sandile Dam, TYR = Tyume River, UD = Umtata Dam, UR = Umtata River

\section{Experimental}

\section{Apparatus}

Analyses were done using a Perkin Elmer AutoSystem XL gas chromatograph fitted with an electron-capture detector. A Quadrex Corporation, New Haven CT, USA bonded-phase fused silica capillary column, methyl $5 \%$ phenyl silicone $(30 \mathrm{~m} \times 0.53 \mathrm{~mm}$ i.d. $\mathrm{x}$ $2 \mu \mathrm{m})$ was used. A glass injector liner $(8 \mathrm{~cm} \times 3 \mathrm{~mm})$, manually packed with silanised glass wool and supplied by Perkin Elmer Instrument Pty, Johannesburg, South Africa was attached to the injector end of the column.

\section{Reagents}

All the solvents used, n-hexane, dichloromethane (DCM), light petroleum, acetone and distilled water were of analytical grade. OCP standards were purchased from Sigma-Aldrich (Germany). All standard solutions were prepared by preparing a stock solution of $1000 \mathrm{mg} / \ell$ in hexane, which was kept in a fridge. These solutions were further diluted as required.

\section{Determination of response factors}

The response factor $(\mathrm{RF})$ of the standard pesticides relative to a (pentachloronitrobenzene) internal standard (I.S), was determined by injecting $1.0 \mathrm{~m} \ell$ of a mixture of the organochlorine standard pesticides and the internal standard at a concentration range of 60 to $400 \mathrm{ng} / \ell$. The response factor was calculated based on the equation below:

Response factor $=\frac{\text { Peak area of the pesticide standard }}{\text { Peak area of the internal standard }}$

\section{Liquid/liquid extraction (LLE)}

All glassware used was washed with liquid soap and rinsed properly with distilled water, and then with pure acetone (analytical grade). They were then baked in an oven at $100^{\circ} \mathrm{C}$ for $24 \mathrm{~h}$ and $1 \ell$ volume of pre-extracted river water was fortified with a pesticide standard mixture, at varying concentrations (between $60 \mathrm{ng} / \ell$ and $400 \mathrm{ng} / \ell$ ) to investigate the potential effect of the matrix on extraction efficiency. The fortified mixture was extracted with $3 \times(15 \mathrm{~m} \ell)$ of dichloromethane. The extracts were combined, dried with anhydrous sodium sulphate and concentrated to about $2 \mathrm{~m} \ell$ using Buchi rotary vacuum evaporator for chromatographic clean-up.

Blank extraction of non-fortified ultra-pure distilled water (prepared by passing doubly distilled water through a Milli-Q purifier system) was carried out using a dichloromethane extraction and chromatographic clean-up method as described below.

\section{Silica gel column chromatography (clean-up)}

A chromatographic column ( $20 \mathrm{~cm}$ x $8 \mathrm{~mm}$ I.D.) was slurry-packed with $5.0 \mathrm{~g}$ of activated analytical grade silica gel, made into a slurry with about $1.2 \% \mathrm{v} / \mathrm{m}$ water-adsorbent in distilled water and stirred before use. Approximately $0.5 \mathrm{~m} \ell$ of anhydrous sodium sulphate was placed at the top of the column to absorb any water in the sample. The column was pre-eluted with $15 \mathrm{~m} \ell$ of light petroleum and prior to the exposure of the sodium sulphate layer to air, the reduced extract from the earlier LLE process was placed in the column and allowed to sink below the sodium sulphate layer. OCPs were then eluted with $2 \times(10 \mathrm{~m} \ell)$ portions of the extracting solvent. The eluate was collected, dried with anhydrous sodium sulphate and evaporated to dryness using a Buchi vacuum rotary evaporator. Internal standard(Pentachloronitrobenzene) was added and the residues were re-constituted with $2 \mathrm{~m} \ell$ of the extracting solvent for gas chromatographic (GC) analysis. 
Figure 2

Gas chromatogram of organochlorine pesticide standards. (1) $\alpha-B H C$,

(2) $H C B$, (3) $\beta-B H C$ (I.S.), internal standard (pentachloronitrobenzene), (4) $\delta$-BHC, (5) Heptachlor, (6) Aldrin, (7) $\gamma$-Chlordane, (8) 2.4'-DDE,

(9) Endosulfan, (10) Dieldrin,

(11) 2.4'-DDD, (12) Endrin,

(13) $4.4^{\prime}-D D D$, (14) $2.4^{\prime}-D D T$, (15) $4.4^{\prime \prime}=D D T$

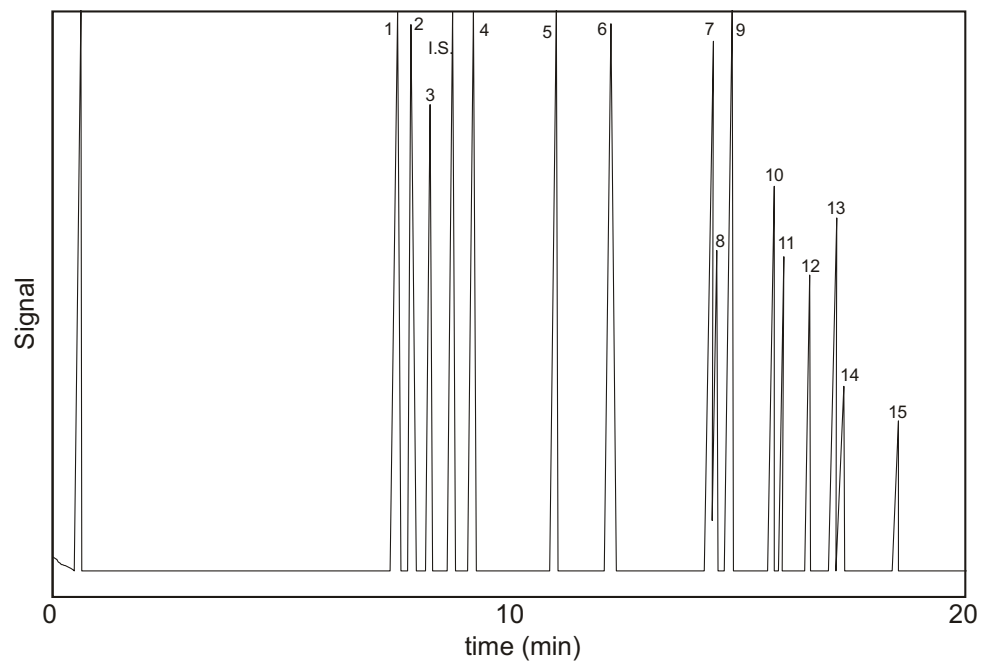

distilled water, assessing recoveries from pre-extracted and fortified river water and sediment samples and performing triplicate analyses of samples from each sampling site per sampling date.

\section{Capillary gas chromatographic analysis} with pesticide standards in the range of $30 \times 10^{3} \mathrm{ng} / \mathrm{kg}$ to $300 \times 10^{3}$ $\mathrm{ng} / \mathrm{kg}$ and then extracted for $10 \mathrm{~h}$ with $120 \mathrm{~m} \ell$ of dichloromethane. The extract was allowed to cool, filtered and then concentrated at $40^{\circ} \mathrm{C}$ to about $2 \mathrm{~m} \ell$ on a vacuum rotary evaporator. The reduced extract was then carried through the column chromatographic cleanup process as described above prior to GC analysis.

\section{Analyses of freshwater and sediment samples}

Approximately $2.5 \ell$ grab water samples were collected in triplicates in clean Winchester bottles from midstream Buffalo River at King William's Town, midstream Keiskamma River at Keiskammahoek, midstream Tyume River at Alice and downstream Swartkops River at Port Elizabeth between January and April 2002. The samples were collected from these sites on the rivers because they were the most accessible. The samples were immediately preserved by adding $5 \mathrm{~m} \ell$ of concentrated $\mathrm{H}_{2} \mathrm{SO}_{4}$ and stored at $4^{\circ} \mathrm{C}$ in a refrigerator until analysed. Sediment samples were collected from the 0 to $5 \mathrm{~cm}$ sediment layers from the same sites as water samples into clean wide-mouth plastic containers and covered immediately after sampling. Samples were kept cool during transportation to the laboratory. At the laboratory, they were frozen at $-18^{\circ} \mathrm{C}$ prior to sample preparation. Sediment samples were air-dried in a circulating air oven at approximately $30^{\circ} \mathrm{C}$ for 2 to $3 \mathrm{~d}$ and sieved.

Ten grams of dried, sieved and pre-extracted sediment sample was weighed into a pre-extracted Whatman extraction thimble and treated as described previously for SE with DCM as extracting solvent. The reduced extract was then carried through the column chromatographic clean-up process as described above prior to GC analysis. Triplicate analyses of the same sediment sample from each site were done.

One litre of an acidified water sample was extracted with dichloromethane as described above. The dichloromethane extract was concentrated to approximately $2 \mathrm{~m} \ell$ and put through the silica gel column chromatographic clean-up as described earlier. Triplicate analyses of the same water sample from each site were done.

\section{Quality control}

Quality control was internal in this study and the measures implemented for this included performing blank analysis of doubly
One microlitre each of processed sample was injected into the GC (split mode - $1 \mathrm{~min}$ ) for analyses. The injector and detector temperatures were maintained at $250^{\circ} \mathrm{C}$ and $350^{\circ} \mathrm{C}$ respectively. The oven temperature was initially maintained at $120^{\circ} \mathrm{C}$, and then programmed to increase at $20^{\circ} \mathrm{C} / \mathrm{min}$ to $150^{\circ} \mathrm{C}$ and ramped to $250^{\circ} \mathrm{C}$ at $5^{\circ} \mathrm{C} . \quad 99.999 \%$ ultra-pure helium and nitrogen gases purchased and supplied by Afrox Limited, South Africa were used as the carrier and make-up gases respectively. The carrier gas flow rate was $2 \mathrm{m \ell} / \mathrm{min}$ while the make-up gas flow was set at $28 \mathrm{m \ell} / \mathrm{min}$ for optimum performance.

\section{Results and discussion}

The gas chromatogram of a mixture of the 15 organochlorine (OC) pesticide standards plus the internal standard is shown in Fig. 2. The 15 pesticides were well resolved and eluted within $22 \mathrm{~min}$. Table 1 shows the retention times and the response factors for the OCPs used.

The mean percentage recoveries of the 15 OCPs from fortified pre-extracted river water by LLE with dichloromethane ranged from $71.03 \% \pm 0.11$ to $101.25 \% \pm 0.02$ (Table 2), which were judged acceptable, hence the choice of the solvent for use in the LLE method for the analyses of environmental river water samples. The results obtained with dichloromethane extraction were comparable to those reported using the USEPA Test Method 608 for organochlorine pesticides via solvent extraction with the same solvent (USEPA, 1984).

The percentage recoveries of OCPs from fortified sediment by Soxhlet extraction method with the same solvent are shown in Table 3. The recoveries of the pesticides ranged from $88.22 \% \pm 0.09$ to $109.63 \% \pm 0.05$, which were judged acceptable for organochlorine pesticide residue analysis in environmental sediment samples collected.

The results of the analyses of organochlorine pesticide residues in environmental river water samples collected from the Buffalo, Tyume, Keiskamma and Swartkops Rivers and from Sandile Dam are shown in Tables 4 to 7. The identities of the OCPs in sample extracts were confirmed by comparing their retention times with those of OCP standards and concentrations were determined by computer calculation making use of both the response factors of the OCPs and the internal standard. Results for the analyses of sediments 


\begin{tabular}{|c|c|c|}
\hline \multicolumn{3}{|c|}{$\begin{array}{l}\text { TABLE } 1 \\
\text { aRetention times } \pm \text { CV and aresponse factors } \\
\pm \text { CV of organochlorine pesticide standards }\end{array}$} \\
\hline OCPs & $\begin{array}{l}\text { Retention } \\
\text { time(min) }\end{array}$ & $\begin{array}{l}\text { Response } \\
\text { factor }\end{array}$ \\
\hline$\alpha-\mathrm{BHC}$ & $8.18 \pm 0.002$ & $1.48 \pm 0.05$ \\
\hline $\mathrm{HCB}$ & $8.55 \pm 0.005$ & $1.17 \pm 0.08$ \\
\hline$\beta-\mathrm{BHC}$ & $8.97 \pm 0.003$ & $1.42 \pm 0.06$ \\
\hline$\delta$-BHC & $9.98 \pm 0.004$ & $1.57 \pm 0.05$ \\
\hline Heptachlor & $11.93 \pm 0.003$ & $1.24 \pm 0.07$ \\
\hline Aldrin & $13.23 \pm 0.001$ & $0.90 \pm 0.09$ \\
\hline$\gamma$-Chlordane & $15.57 \pm 0.001$ & $1.12 \pm 0.10$ \\
\hline 2,4-DDE & $15.70 \pm 0.001$ & $1.93 \pm 0.08$ \\
\hline Endosulfan & $16.06 \pm 0.001$ & $0.88 \pm 0.13$ \\
\hline Dieldrin & $17.04 \pm 0.002$ & $0.63 \pm 0.30$ \\
\hline $2,4^{\prime}-\mathrm{DDD}$ & $17.24 \pm 0.001$ & $1.67 \pm 0.11$ \\
\hline Endrin & $17.83 \pm 0.001$ & $1.81 \pm 0.11$ \\
\hline $4,4^{\prime}-\mathrm{DDD}$ & $18.47 \pm 0.001$ & $1.73 \pm 0.11$ \\
\hline $2,4^{\prime}-\mathrm{DDT}$ & $18.63 \pm 0.001$ & $1.33 \pm 0.17$ \\
\hline $4,4^{\prime}-\mathrm{DDT}$ & $19.91 \pm 0.001$ & $1.28 \pm 0.29$ \\
\hline $\begin{array}{l}\text { Pentachloro } \\
\text { nitrobenzene }\end{array}$ & $9.49 \pm 0.21$ & -- \\
\hline \multicolumn{3}{|c|}{${ }^{a}$ Values are mean of 6 injections } \\
\hline
\end{tabular}

\begin{tabular}{|c|c|c|c|}
\hline \multicolumn{4}{|c|}{$\begin{array}{l}\text { TABLE2 } \\
\text { aMean \% recoveries of organochlorine pesticide } \\
\text { standards added to pre-extracted river water by LLE } \\
\text { with dichloromethane as the extracting solvent }\end{array}$} \\
\hline $\begin{array}{l}\text { Organo- } \\
\text { chlorine } \\
\text { pesticides }\end{array}$ & $\begin{array}{l}\text { Spiked } \\
\text { at }(\mathrm{ng} / \ell)\end{array}$ & $\begin{array}{c}\% \text { Recovery } \\
\text { +CV }\end{array}$ & $\begin{array}{l}\text { Limits } \\
\text { of } \\
\text { Detection† } \\
\quad(\mathrm{ng} / \ell)\end{array}$ \\
\hline$\alpha-\mathrm{BHC}$ & 60 & $101.25 \pm 0.02$ & 18 \\
\hline HCB & 200 & $93.50 \pm 0.12$ & 18.6 \\
\hline$\beta-\mathrm{BHC}$ & 200 & $93.37 \pm 0.71$ & 7.7 \\
\hline$\delta$-BHC & 200 & $100.13 \pm 0.03$ & 15 \\
\hline Heptachlor & 140 & $89.29 \pm 0.03$ & 12 \\
\hline Aldrin & 160 & $85.00 \pm 0.04$ & 7.5 \\
\hline$\gamma$-Chlordane & 160 & $78.13 \pm 0.04$ & 20.6 \\
\hline $2,4^{\prime}-\mathrm{DDE}$ & 400 & $83.94 \pm 0.03$ & 7.7 \\
\hline Endosulfan & 140 & $78.69 \pm 0.07$ & 18.5 \\
\hline Dieldrin & 160 & $71.03 \pm 0.11$ & 5.7 \\
\hline $2,4^{\prime}-\mathrm{DDD}$ & 400 & $83.78 \pm 0.10$ & 5.5 \\
\hline Endrin & 400 & $91.46 \pm 0.03$ & 14.7 \\
\hline 4,4'-DDD & 400 & $80.79 \pm 0.08$ & 13.4 \\
\hline $2,4^{\prime}-\mathrm{DDT}$ & 400 & $77.16 \pm 0.12$ & 6.0 \\
\hline $4,4^{\prime}$-DDT & 400 & $80.42 \pm 0.14$ & 18.9 \\
\hline \multicolumn{4}{|c|}{$\begin{array}{l}\text { aValues are mean of triplicate analyses. } \\
\dagger \text { Calculated from the linear regression equation of the calibra- } \\
\text { tion curve of each organochlorine pesticide standard (Miller and } \\
\text { Miller, 1998) } \\
\text { CV }=\text { Coefficient of variation }\end{array}$} \\
\hline
\end{tabular}

\begin{tabular}{|c|c|c|}
\hline \multicolumn{3}{|c|}{$\begin{array}{c}\text { TABLE } 3 \\
\text { alean \% recoveries of organochlorine pesticide } \\
\text { standards added to pre-extracted sediment by } \\
\text { Soxhlet extraction with dichloromethane as } \\
\text { extracting solvent }\end{array}$} \\
\hline OCPs & $\begin{array}{l}\text { Spiked at } \\
(\mathrm{ng} / \mathrm{kg})\end{array}$ & $\begin{array}{c}\% \text { Recovery }^{\mathrm{a}} \\
\pm \mathrm{CV}\end{array}$ \\
\hline $\begin{array}{l}\alpha \text {-BHC } \\
\text { HCB } \\
\beta \text {-BHC } \\
\delta \text {-BHC } \\
\text { Heptachlor } \\
\text { Aldrin } \\
\gamma \text {-Chlordane } \\
\text { 2,4-DDE } \\
\text { Endosulfan } \\
\text { Dieldrin } \\
\text { 2,4-DDD } \\
\text { Endrin } \\
\text { 4,4-DDD } \\
\text { 2,4-DDT } \\
\text { 4,4-DDT }\end{array}$ & $\begin{array}{c}30 \times 10^{3} \\
150 \times 10^{3} \\
150 \times 10^{3} \\
75 \times 10^{3} \\
100 \times 10^{3} \\
120 \times 10^{3} \\
150 \times 10^{3} \\
300 \times 10^{3} \\
100 \times 10^{3} \\
200 \times 10^{3} \\
300 \times 10^{3} \\
300 \times 10^{3} \\
300 \times 10^{3} \\
300 \times 10^{3} \\
300 \times 10^{3}\end{array}$ & $\begin{array}{c}96.09 \pm 0.01 \\
98.87 \pm 0.11 \\
109.63 \pm 0.05 \\
98.48 \pm 0.08 \\
98.88 \pm 0.02 \\
97.12 \pm 0.05 \\
96.89 \pm 0.01 \\
96.03 \pm 0.05 \\
97.55 \pm 0.09 \\
96.17 \pm 0.04 \\
100.61 \pm 0.05 \\
88.22 \pm 0.09 \\
97.84 \pm 0.03 \\
99.14 \pm 0.09 \\
90.19 \pm 0.02\end{array}$ \\
\hline \multicolumn{3}{|c|}{$\begin{array}{l}{ }^{\mathrm{a}} \text { Values are mean of triplicate analyses } \\
\mathrm{CV}=\text { Coefficient of variation }\end{array}$} \\
\hline
\end{tabular}

\begin{tabular}{|c|c|c|c|}
\hline \multicolumn{4}{|c|}{$\begin{array}{c}\text { TABLE4 } \\
\text { aOrganochlorine pesticide levels }(\mathrm{ng} / \ell \pm \mathrm{CV}) \text { in fresh- } \\
\text { water samples }\end{array}$} \\
\hline $\begin{array}{l}\text { Sampling } \\
\text { date }\end{array}$ & $10 / 01 / 2002$ & $10 / 01 / 2002$ & $10 / 01 / 2002$ \\
\hline OCPs & ${ }^{b}(B R)_{1}$ & ${ }^{\mathrm{b}}(\mathrm{BR})_{2}$ & ${ }^{b}(B R)_{3}$ \\
\hline $\begin{array}{l}\alpha \text {-BHC } \\
\text { HCB } \\
\beta \text {-BHC } \\
\delta \text {-BHC } \\
\text { Heptachlor } \\
\text { Aldrin } \\
\gamma \text {-Chlordane } \\
2,4 \text { '-DDE } \\
\text { Endosulfan } \\
\text { Dieldrin } \\
2,4^{\prime}-\text { DDD } \\
\text { Endrin } \\
4,4 \text { '-DDD } \\
2,4 \text { '-DDT } \\
4,4^{\prime} \text {-DDT }\end{array}$ & $\begin{array}{c}\text { Trace } \\
\text { Trace } \\
200 \pm 0.0002 \\
100 \pm 0.0004 \\
\text { Trace } \\
\text { Trace } \\
\text { Trace } \\
\text { Trace } \\
\text { Trace } \\
\text { Trace } \\
\text { Trace } \\
\text { Trace } \\
\text { Trace } \\
100 \pm 0.0002 \\
140 \pm 0.0004\end{array}$ & $\begin{array}{c}20 \pm 0.001 \\
100 \pm 0.0002 \\
30 \pm 0.0003 \\
80 \pm 0.004 \\
200 \pm 0.0001 \\
20 \pm 0.002 \\
100 \pm 0.0005 \\
100 \pm 0.0003 \\
100 \pm 0.0004 \\
100 \pm 0.0002 \\
30 \pm 0.001 \\
40 \pm 0.0005 \\
100 \pm 0.0005 \\
100 \pm 0.0002 \\
20 \pm 0.003\end{array}$ & $\begin{aligned} 50 & \pm 0.0002 \\
80 & \pm 0.0004 \\
450 & \pm 0.0002 \\
140 & \pm 0.0004 \\
171 & \pm 0.0008 \\
120 & \pm 0.0002 \\
120 & \pm 0.0003 \\
240 & \pm 0.0003 \\
50 & \pm 0.0004 \\
60 & \pm 0.0007 \\
180 & \pm 0.0003 \\
30 & \pm 0.002 \\
210 & \pm 0.0001 \\
260 & \pm 0.0006 \\
160 & \pm 0.0003\end{aligned}$ \\
\hline \multicolumn{4}{|c|}{$\begin{array}{l}{ }^{a} \text { Mean of triplicate analyses, }{ }^{b} \text { Buffalo River } \\
\text { CV }=\text { Coefficient of variation } \\
\text { Trace }=<\text { Detection limit } \\
(B R)_{1},(B R)_{2} \text { and }(B R)_{3}=\text { samples from different locations } \\
\text { but around the same site }\end{array}$} \\
\hline
\end{tabular}


are shown in Tables 8 to 11. Levels of OCPs ranged from trace $\left(2,4^{\prime}\right.$ DDD) $\mathrm{ng} / \ell$ to $450 \mathrm{ng} / \ell$ ( $\beta$-BHC) in the Buffalo River, from trace $(2,4$ 'DDE) to $180 \mathrm{ng} / \ell$ ( $\beta$-BHC) in the KeiskammaRiverand from trace (2,4'DDT) to $130 \mathrm{ng} / \ell$ (HCB) in the Tyume River. The concentration of pesticides in the Swartkops River varied between trace (2,4'-DDT) and $100 \mathrm{ng} / \ell\left(2,4^{\prime}\right.$-DDE). Our values are much higher than those reported by Grobler et al. (1994) for Olifants River and those reported by Weaver (1993) for Hex River where no OCP was detected but much lower than those reported by London etal.(2000) for Hex. Piketburg and Grabouw/ Vyeboom Rivers in the Western Cape Province(OCPs, $50 \mathrm{ng} / \ell$ to $1000 \mathrm{ng} /$ e). $37 \%$ of the samples analysed by London et al. (2000) were detected above the EU limit of $100 \mathrm{ng} / \ell$ for endosulfan. $100 \%$ of the samples analysed in this study were detected below the EU limit for endosulfan (European Community, 1980). Among the OCPs detected at levels $>100 \mathrm{ng} / \ell$ in our study were HCB, $\beta$-BHC, $\delta$-BHC, heptachlor and ¿DDT. In the river sediments, the levels of OCPs ranged from trace $\left(2,4^{\prime}\right.$-DDT) to $184 \times 10^{3} \mathrm{ng} / \mathrm{kg}$ (heptachlor) in the Buffalo River, from trace (2,4'-DDT, dieldrin) to $16 \times 10^{3}$ $\mathrm{ng} / \mathrm{kg}(\gamma$-chlordane $)$ in the Keiskamma River and from trace (2,4'-DDT, dieldrin) to $19 \times 10^{3} \mathrm{ng} / \mathrm{kg}\left(2,4^{\prime}-\mathrm{DDD}\right)$ in the Tyume River. The residues pesticides in the Swartkops River varied between trace (2,4'-DDT, 2,4'-DDD, dieldrin) and $30 \times 10^{3} \mathrm{ng} / \mathrm{kg}(\beta-\mathrm{BHC})$. These levels of OCPs were significantly lower than the levels found in river sediment from the Olifants River by Grobler et al.(1994). The residues detected in this study were also of lower values than those detected in sediment by Naude et al. (1998), which ranged from $8.7 \times 10^{3} \mathrm{ng} / \mathrm{kg}$ to $320 \times 10^{3} \mathrm{ng} / \mathrm{kg}$ for DDT, from $12 \mathrm{x}$ $10^{3} \mathrm{ng} / \mathrm{kg}$ to $374 \times 10^{3} \mathrm{ng} / \mathrm{kg}$ for DDD and from $23.5 \times 10^{3} \mathrm{ng} / \mathrm{kg}$ to $346 \times 10^{3}$ $\mathrm{ng} / \mathrm{kg}$ for DDE.

The highest residue concentration detected in river water ( $\beta$-BHC, $450 \mathrm{ng} / \ell$ ) was found in the Buffalo River. The highest residue concentration detected in sediment (heptachlor, $184 \times 10^{3} \mathrm{ng} / \mathrm{kg}$ ) was also found in the same river. Residues of DDT and its metabolites ranged from trace to 260 $\mathrm{ng} / \ell$ in the rivers with the highest value detected in the Buffalo River (Tables 4 to 7). High levels of $\beta$-BHC were also detected in the Keiskamma, Keiskammahoek (180 ng/ $\ell)$ and the Tyume (130
TABLE 5

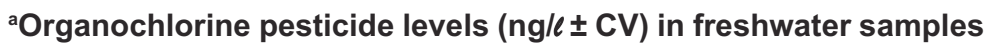

\begin{tabular}{|l|c|c|c|c|c|}
\hline $\begin{array}{l}\text { Sampling } \\
\text { date }\end{array}$ & $\mathbf{1 2 / 0 3 / 0 2}$ & $\mathbf{1 2} \mathbf{~ / 0 3 / 0 2}$ & $\mathbf{1 2 ~ / 0 3 / 0 2}$ & $\mathbf{1 2 ~ / 0 3 / 0 2}$ & $\mathbf{1 2 ~ / 0 3 / 0 2}$ \\
\hline OCPs & & & & & \\
\hline$\alpha$-BHC & $70 \pm 0.0001$ & $50 \pm 0.0006$ & $40 \pm 0.002$ & $40 \pm 0.0008$ & $90 \pm 0.0002$ \\
HCB & $150 \pm 0.0001$ & $20 \pm 0.001$ & $30 \pm 0.0003$ & $20 \pm 0.003$ & $30 \pm 0.002$ \\
$\beta$-BHC & $30 \pm 0.0007$ & $50 \pm 0.0004$ & $180 \pm 0.002$ & $85 \pm 0.0007$ & $40 \pm 0.002$ \\
$\delta$-BHC & $20 \pm 0.003$ & $20 \pm 0.003$ & $110 \pm 0.0005$ & $10 \pm 0.004$ & $20 \pm 0.001$ \\
Heptachlor & $20 \pm 0.001$ & $30 \pm 0.0003$ & $50 \pm 0.0002$ & $20 \pm 0.004$ & $70 \pm 0.0006$ \\
Aldrin & $25 \pm 0.0004$ & $70 \pm 0.0009$ & $80 \pm 0.001$ & $90 \pm 0.001$ & $10 \pm 0.002$ \\
$\gamma$-Chlordane & $40 \pm 0.0005$ & $50 \pm 0.0004$ & $40 \pm 0.0003$ & $50 \pm 0.0008$ & $90 \pm 0.0006$ \\
2,4'-DDE & $20 \pm 0.0005$ & $20 \pm 0.003$ & $30 \pm 0.001$ & $40 \pm 0.003$ & $100 \pm 0.0008$ \\
Endosulfan & $10 \pm 0.005$ & $80 \pm 0.001$ & Trace & Trace & Trace \\
Dieldrin & $30 \pm 0.001$ & $30 \pm 0.001$ & $10 \pm 0.002$ & $60 \pm 0.001$ & $10 \pm 0.003$ \\
2,4'-DDD & $30 \pm 0.0003$ & $40 \pm 0.0003$ & $40 \pm 0.0005$ & $120 \pm 0.001$ & $30 \pm 0.001$ \\
Endrin & $20 \pm 0.0005$ & $20 \pm 0.001$ & $30 \pm 0.0003$ & $20 \pm 0.002$ & $10 \pm 0.002$ \\
4,4'-DDD & $20 \pm 0.002$ & $20 \pm 0.0005$ & $20 \pm 0.0005$ & $30 \pm 0.003$ & $30 \pm 0.002$ \\
2,4'-DDT & $40 \pm 0.002$ & $20 \pm 0.001$ & $30 \pm 0.0007$ & $50 \pm 0.001$ & $20 \pm 0.001$ \\
4,4'-DDT & $50 \pm 0.0008$ & $20 \pm 0.001$ & $80 \pm 0.0008$ & $50 \pm 0.0006$ & $30 \pm 0.0003$ \\
\hline
\end{tabular}

${ }^{\mathrm{a}}$ Mean of triplicate analyses, ${ }^{\mathrm{b}}$ Buffalo River, ${ }^{\mathrm{c}}$ Sandile Dam, ${ }^{\mathrm{d}}$ Keiskamma River, ${ }^{\mathrm{e}}$ Tyume

River and ${ }^{\text {SSwartkops River }}$

$\mathrm{CV}=$ coefficient of variation

Trace $=<$ detection limit.

\section{TABLE 6}

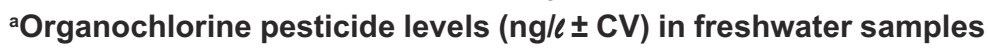

\begin{tabular}{|c|c|c|c|c|c|}
\hline $\begin{array}{l}\text { Sampling } \\
\text { date }\end{array}$ & $26 / 03 / 02$ & $26 / 03 / 02$ & $26 / 03 / 02$ & $26 / 03 / 02$ & $26 / 03 / 02$ \\
\hline OCPs & ${ }^{b}(B R)$ & ${ }^{c}(\mathrm{SD})$ & ${ }^{d}(K R)$ & e(TYR) & ${ }^{f}$ (SKR) \\
\hline$\alpha-\mathrm{BHC}$ & $60 \pm 0.0005$ & $20 \pm 0.002$ & $40 \pm 0.0008$ & $70 \pm 0.0007$ & $20 \pm 0.002$ \\
\hline $\mathrm{HCB}$ & $20 \pm 0.002$ & $20 \pm 0.003$ & $20 \pm 0.002$ & $60 \pm 0.002$ & $60 \pm 0.0003$ \\
\hline$\beta$-BHC & $20 \pm 0.001$ & $40 \pm 0.002$ & $40 \pm 0.002$ & $30 \pm 0.003$ & $10 \pm 0.003$ \\
\hline$\delta$-BHC & $70 \pm 0.0007$ & $20 \pm 0.003$ & $20 \pm 0.002$ & $120 \pm 0.001$ & Trace \\
\hline Heptachlor & Trace & $40 \pm 0.004$ & Trace & $50 \pm 0.0006$ & Trace \\
\hline Aldrin & $30 \pm 0.0003$ & $20 \pm 0.003$ & $70 \pm 0.0004$ & $20 \pm 0.003$ & Trace \\
\hline$\gamma$-Chlordane & Trace & $60 \pm 0.002$ & $70 \pm 0.002$ & $10 \pm 0.004$ & Trace \\
\hline 2,4'-DDE & $40 \pm 0.003$ & Trace & Trace & Trace & Trace \\
\hline Endosulfan & Trace & $20 \pm 0.004$ & Trace & Trace & $20 \pm 0.002$ \\
\hline Dieldrin & $30 \pm 0.002$ & $10 \pm 0.005$ & $10 \pm 0.004$ & $50 \pm 0.0008$ & $20 \pm 0.004$ \\
\hline $2,4^{\prime}-\mathrm{DDD}$ & $30 \pm 0.002$ & $20 \pm 0.003$ & $20 \pm 0.004$ & $20 \pm 0.001$ & $40 \pm 0.0008$ \\
\hline Endrin & Trace & Trace & Trace & $70 \pm 0.003$ & $70 \pm 0.002$ \\
\hline $4,4^{\prime}$-DDD & $20 \pm 0.005$ & Trace & $20 \pm 0.005$ & $30 \pm 0.001$ & Trace \\
\hline $2,4^{\prime}-\mathrm{DDT}$ & $40 \pm 0.0005$ & Trace & $10 \pm 0.003$ & Trace & $30 \pm 0.002$ \\
\hline $4,4^{\prime}$-DDT & $30 \pm 0.002$ & Trace & $50 \pm 0.001$ & $20 \pm 0.004$ & $30 \pm 0.0003$ \\
\hline
\end{tabular}

${ }^{\mathrm{a}}$ Mean of triplicate analyses, ${ }^{\mathrm{b}}$ Buffalo River, ${ }^{\mathrm{c}}$ Sandile Dam, ${ }^{\mathrm{d}}$ Keiskamma River, ${ }^{\mathrm{e}}$ Tyume River and ${ }^{\mathrm{f}}$ Swartkops River

$\mathrm{CV}=$ Coefficient of variation $\mathrm{ng} / \ell)$ Rivers though the highest value for the OCP $(200 \mathrm{ng} / \ell)$ was detected in the Buffalo River. In addition the highest concentrations

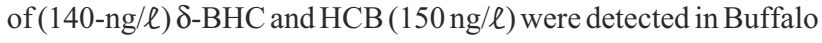
River though relatively high value of HCB (130 ng/ $\ell$ ) was also detected in the Tyume River. For sediment the highest levels of 


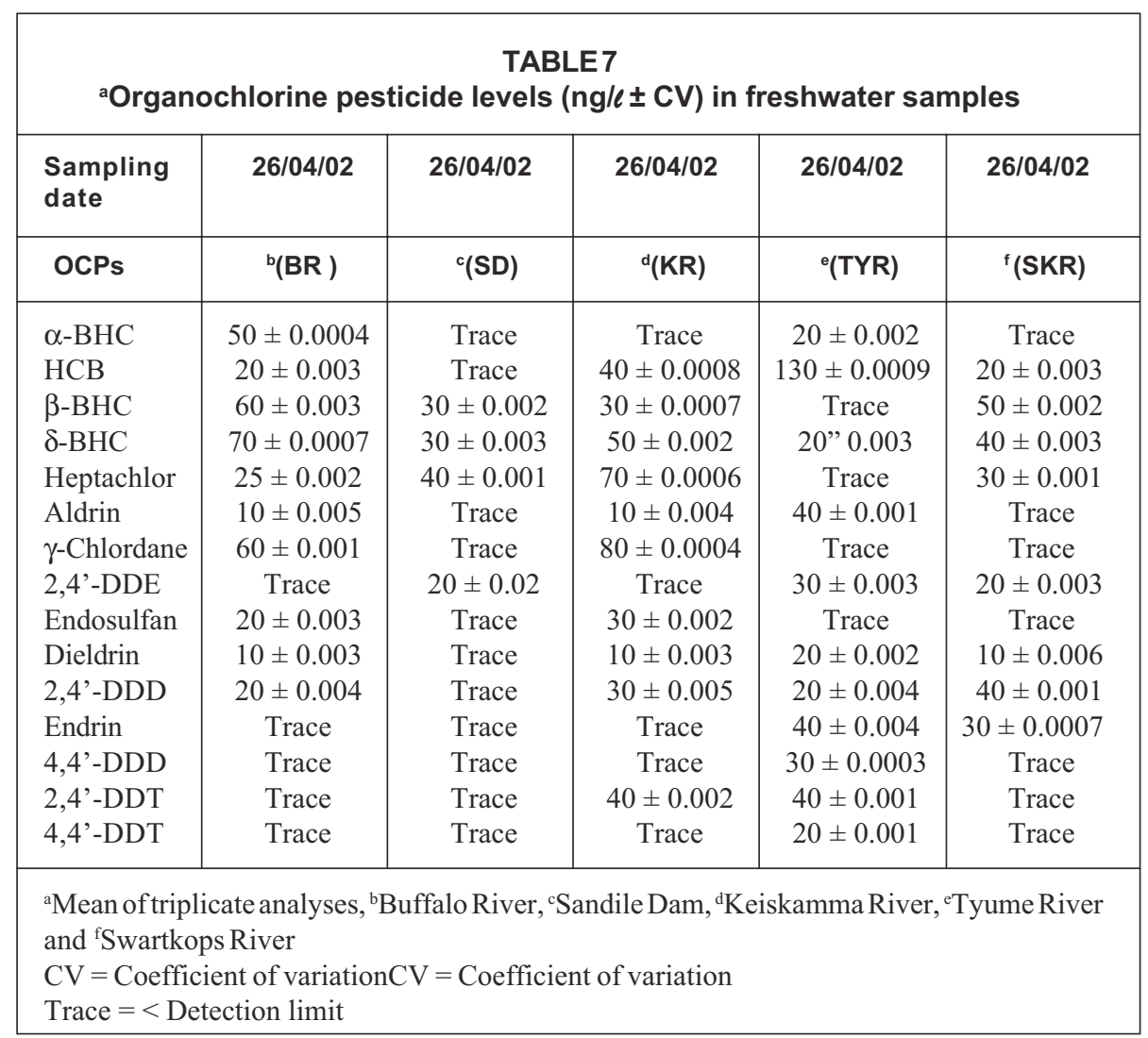

the levels of OCPs were relatively lower in the Swartkops River. This river flows through Port Elizabeth and commercial agricultural areas. The Buffalo, Tyume and Keiskamma Rivers pass through agricultural lands in the Eastern Cape where rural agriculture is prevalent. Thus high levels of some pesticide residues in them are probably due to illegal use of some OCPs in the rivers' catchment areas by rural farmers. OCPs such as endosulfan and chlordane (the latter only used for termite control in structures) are still legally being used in South Africa, however, the low concentrations of these pesticides in the rivers suggests their not common use in the study areas. The sources of OCPs such as heptachlor, $\beta$-BHC and $\delta$-BHC in the water systems are probably from diffuse sources such as runoff from agricultural lands. All the rivers pass through agricultural areas in the province. $\beta$-BHC and $\delta$-BHC could also have industrial sources especially in the Buffalo River, which receives some industrial effluents from the King William's Town area. The presence of DDT

\begin{tabular}{|c|c|c|c|}
\hline \multicolumn{4}{|c|}{$\begin{array}{c}\text { TABLE } 8 \\
\text { aOrganochlorine pesticide levels }(\mathrm{ng} / \mathrm{kg} \pm \mathrm{CV}) \text { in sediment } \\
\text { samples }\end{array}$} \\
\hline $\begin{array}{l}\text { Sampling } \\
\text { date }\end{array}$ & $10 / 01 / 2002$ & $10 / 01 / 2002$ & $10 / 01 / 2002$ \\
\hline OCPs & ${ }^{b}(B R)_{1}$ & ${ }^{b}(B R)_{2}$ & ${ }^{b}(B R)_{3}$ \\
\hline $\begin{array}{l}\alpha \text {-BHC } \\
\text { HCB } \\
\beta \text {-BHC } \\
\delta \text {-BHC } \\
\text { Heptachlor } \\
\text { Aldrin } \\
\gamma \text {-Chlordane } \\
2,4^{\prime} \text {-DDE } \\
\text { Endosulfan } \\
\text { Dieldrin } \\
2,4^{\prime} \text {-DDD } \\
\text { Endrin } \\
4,4^{\prime} \text {-DDD } \\
2,4^{\prime} \text {-DDT } \\
4,4^{\prime} \text {-DDT }\end{array}$ & $\begin{array}{c}90 \times 10^{3} \pm 0.3 \\
34 \times 10^{3} \pm 0.6 \\
81.5 \times 10^{3} \pm 0.5 \\
56 \times 10^{3} \pm 0.4 \\
36.7 \times 10^{3} \pm 1.4 \\
70.2 \times 10^{3} \pm 2.6 \\
92 \times 10^{3} \pm 0.8 \\
\text { Trace } \\
92 \times 10^{3} \pm 0.9 \\
\text { Trace } \\
94 \times 10^{3} \pm 1.1 \\
100 \times 10^{3} \pm 0.5 \\
\text { Trace } \\
\text { Trace } \\
110 \pm 0.2\end{array}$ & $\begin{array}{c}19.1 \times 10^{3} \pm 4.2 \\
30 \times 10^{3} \pm 1.7 \\
72.7 \times 10^{3} \pm 0.1 \\
74.3 \times 10^{3} " 0.4 \\
95 \times 10^{3} \pm 0.1 \\
\text { Trace } \\
\text { Trace } \\
\text { Trace } \\
\text { Trace } \\
\text { Trace } \\
\text { Trace } \\
\text { Trace } \\
\text { Trace } \\
\text { Trace } \\
\text { Trace }\end{array}$ & $\begin{array}{c}23 \times 10^{3} \pm 1.3 \\
24.6 \times 10^{3} \pm 1.2 \\
75.3 \times 10^{3} \pm 0.9 \\
177 \times 10^{3} \pm 0.3 \\
184 \times 10^{3} \pm 0.7 \\
30.7 \times 10^{3} \pm 2.0 \\
117 \times 10^{3} \pm 0.3 \\
20.6 \times 10^{3} \pm 0.17 \\
72 \times 10^{3} \pm 8.3 \\
60 \times 10^{3} \pm 0.2 \\
39.5 \times 10^{3} \pm 1.5 \\
38.4 \times 10^{3} \pm 0.5 \\
47.7 \times 10^{3} \pm 0.2 \\
109 \times 10^{3} \pm 0.4 \\
33.6 \times 10^{3} \pm 1.8\end{array}$ \\
\hline \multicolumn{4}{|c|}{$\begin{array}{l}\text { aMean of triplicate analyses, }{ }^{b} \text { Buffalo River. } \\
\mathrm{CV}=\text { Coefficient of deviation } \\
\text { Trace }=<\text { Detection limit }\end{array}$} \\
\hline
\end{tabular}
and some of its degradation residues in the water systems can be attributed to their wide usage before their banning (the use of DDT is still strictly controlled in South Africa) (Van Dyk et al., 1982; Davies and Randall, 1989). Since they are persistent enough and degrade slowly and easily accumulate, the transportation of these pesticides both sorbed onto solids and dissolved in the surface water can be expected (Aydin and Yurdin, 1999).

Results of analyses of samples collected from the rivers showed that the concentrations of most of the OCP residues detected in water were below the maximum acceptable concentration of $100 \mathrm{ng} / \ell$ value set by the European Union (EU) for the protection of human health (European Community, 1980). However, some elevated levels of $450 \mathrm{ng} / \ell, 200 \mathrm{ng} / \ell, 260 \mathrm{ng} / \ell, 210 \mathrm{ng} / \ell$ and $240 \mathrm{ng} / \ell$ were detected in $\beta$-BHC, heptachlor, $2,4^{\prime}$-DDT, 4,4'-DDD and 2,4'-DDE respectively in the Buffalo River. These elevated concentrations give cause for concern. In many rural areas, drinking water is sourced directly from the contaminated rivers and this could expose some of the primary users of water from these rivers to these residues with potential health effects. Some of the residues detected in the water sources like chlordane, heptachlor, 2,4'-DDT, 4,4'-DDT, 2,4'-DDE and endosulfan are known to have synergistic and cumulative effects on the endocrine systems (Soto et al., 1994; Safe, 2001). Thus the population and the environment in the study area could probably be at risk if the trend is not checked.

Standards to protect aquatic ecosystems are far lower than those for human health. The South African Target $\alpha$-BHC $\left(90 \times 10^{3} \mathrm{ng} / \mathrm{kg}\right), \beta-\mathrm{BHC}\left(81.5 \times 10^{3} \mathrm{ng} / \mathrm{kg}\right), \delta$-BHC (177 x $\left.10^{3} \mathrm{ng} / \mathrm{kg}\right)$ and heptachlor $\left(184 \times 10^{3} \mathrm{ng} / \mathrm{g}\right)$ were detected in the Buffalo River. Similarly the highest values of aldrin, $\gamma$-chlordane, endosulfan, and $\Sigma$ DDT were detected in the same river. Generally, Water Quality guidelines to protect aquatic ecosystems are aldrin $10 \mathrm{ng} / \ell$, chlordane $25 \mathrm{n} / \ell$, DDT $1.5 \mathrm{ng} / \ell$, dieldrin $5 \mathrm{ng} / \ell$, endosulfan $3 \mathrm{ng} / \ell$, endrin $2 \mathrm{ng} / \ell$ and heptachlor $5 \mathrm{ng} / \ell$ (DWAF, 1996). The levels detected in some of the water samples were higher than these 
guideline values and may thus affect the fitness of species in the river in terms of health, reproduction and behaviour (DWAF, 1996).

In the Sandile Dam, levels of OCPs ranged from trace (2,4'-DDT) to $80 \mathrm{ng} / \ell$ (endosulfan). The Sandile Dam is situated on the Keiskamma River. Water from this dam is treated to supply the Keiskammahoek local government area and the Middledrift district with tapped drinking water. The presence of OCPs in this impoundment gives cause for concern, especially the presence of endocrine disrupting (ED) pesticides such as endosulfan, which may have health implications for the rural communities who are secondary users of water from the dam. Water treatment in general does not remove pesticides.

\section{Conclusion}

This study showed that solvent extraction with DCM is an accurate and reliable method for OCP residue analyses in environmental water samples. It also showed SE extraction with DCM to be a reliable method for OCP determination in sediments. Several OCPs were detected in the water systems including some endocrine disrupting compounds such as endosulfan, heptachlor, 2,4'-DDT, 4,4'-DDT and 2,4'-DDE.

\section{Acknowledgement}

The authors would like to thank the National Research Foundation (NRF), South Africa, for the research grant.

\section{References}

AYDIN A and YURDIN T (1999) Residues of organochlorine pesticides in water sources of Istanbul. Water Air Soil Pollut. 111 385398.

COCCO P, BLAIR A, CONGIA P, SABA G, FLORE C, ECCA MR and PALMAS C (1997) Proportional mortality of dichlorodiphenyl-trichloroethane (DDT) in worker: A preliminary report. Arch. Environ. Health 52 299303.

DAVIES DL and BARLOW HL (1995) Can environmental estrogen cause breast cancer? Sci. Am. October. 144-147.

DAVIES R and RANDALL RM (1989) Historical and Geological Patterns in Eggshell Thickness of African Fish Eagle, Haliaeetus vocifer. Meyburg/Chancellor: London. and S'Swartkops River

Trace $=<$ Detection limit and ${ }^{\text {SSwartkops River }}$

Trace $=<$ Detection limit
TABLE 9

${ }^{\text {a } O r g a n o c h l o r i n e ~ p e s t i c i d e ~ l e v e l s ~}(\mathrm{ng} / \mathrm{kg} \pm \mathrm{CV})$ in sediment samples

\begin{tabular}{|c|c|c|c|c|}
\hline $\begin{array}{l}\text { Sampling } \\
\text { date }\end{array}$ & $12 / 03 / 02$ & $12 / 03 / 02$ & $12 / 03 / 02$ & $12 / 03 / 02$ \\
\hline OCPs & b(BR ) & ${ }^{d}(K R)$ & e(TYR) & ${ }^{f}(\mathrm{SKR})$ \\
\hline$\alpha-\mathrm{BHC}$ & $5.0 \times 10^{3} \pm 6.0$ & $2.0 \times 10^{3} \pm 20.0$ & $3.0 \times 10^{3} \pm 10.0$ & $5.0 \times 10^{3} \pm 6.0$ \\
\hline $\mathrm{HCB}$ & $9.0 \times 10^{3} \pm 6.7$ & $6.0 \times 10^{3} \pm 23.3$ & $4.0 \times 10^{3} \pm 35.0$ & $5.0 \times 10^{3} \pm 12.0$ \\
\hline$\beta-\mathrm{BHC}$ & $11 \times 10^{3} \pm 4.5$ & $6.0 \times 10^{3} \pm 3.3$ & $8.9 \times 10^{3} \pm 6.7$ & $30 \times 10^{3} \pm 2.7$ \\
\hline$\delta$-BHC & $3.0 \times 10^{3} \pm 50$ & $8.0 \times 10^{3} \pm 6.3$ & $7.8 \times 10^{3} \pm 5.1$ & Trace \\
\hline Heptachlor & Trace & $2.0 \times 10^{3} \pm 30.0$ & $6.0 \times 10^{3} \pm 16.7$ & Trace \\
\hline Aldrin & $5.0 \times 10^{3} \pm 8.0$ & $5.0 \times 10^{3} \pm 6.0$ & $9.0 \times 10^{3} \pm 8.9$ & $2.0 \times 10^{3} \pm 25.0$ \\
\hline$\gamma$-Chlordane & Trace & $16.0 \times 10^{3} \pm 2.5$ & Trace & Trace \\
\hline 2,4'-DDE & Trace & Trace & $4.0 \times 10^{3} \pm 5.0$ & $21.0 \times 10^{3} \pm 3.3$ \\
\hline Endosulfan & $3.0 \times 10^{3} \pm 6.7$ & Trace & Trace & $15.3 \times 10^{3} \pm 10.5$ \\
\hline Dieldrin & $18.0 \times 10^{3} \pm 3.3$ & $6.0 \times 10^{3} \pm 28.3$ & Trace & Trace \\
\hline 2,4'-DDD & $2.0 \times 10^{3} \pm 10.0$ & $15.0 \times 10^{3} \pm 8.7$ & $19.0 \times 10^{3} \pm 6.8$ & Trace \\
\hline Endrin & $1.0 \times 10^{3} \pm 70.0$ & $8.0 \times 10^{3} " 5.0$ & $17.0 \times 10^{3} \pm 3.5$ & Trace \\
\hline 4,4'-DDD & $12 \times 10^{3} \pm 2.5$ & $5.0 \times 10^{3} \pm 14.0$ & $6.0 \times 10^{3} \pm 3.3$ & Trace \\
\hline $2,4^{\prime}$-DDT & $11 \times 10^{3} \pm 4.5$ & Trace & $3.0 \times 10^{3 " \prime} 16.7$ & Trace \\
\hline 4,4'-DDT & $19 \times 10^{3} \pm 6.8$ & $3.0 \times 10^{3} \pm 16.7$ & $4.0 \times 10^{3} \pm 5.0$ & Trace \\
\hline
\end{tabular}

${ }^{\mathrm{a}}$ Mean of triplicate analyses, ${ }^{\mathrm{b}}$ Buffalo River, ${ }^{\mathrm{c}}$ Sandile Dam, ${ }^{\mathrm{d}}$ Keiskamma River, ${ }^{\mathrm{e}}$ Tyume River

$\mathrm{CV}=$ Coefficient of variation

TABLE10

aOrganochlorine pesticide levels (ng/kg $\pm \mathrm{CV}$ ) in sediment samples

\begin{tabular}{|l|c|c|c|c|}
\hline $\begin{array}{l}\text { Sampling } \\
\text { date }\end{array}$ & $\mathbf{2 6 / 0 3 / 0 2}$ & $\mathbf{2 6 / 0 3 / 0 2}$ & $\mathbf{2 6 / 0 3 / 0 2}$ & $\mathbf{2 6 / 0 3 / 0 2}$ \\
\hline \multicolumn{1}{|c}{ OCPs } & ${ }^{\mathrm{b}}(\mathbf{B R})$ & ${ }^{\mathrm{d}} \mathbf{( K R )}$ & ${ }^{\mathrm{e}} \mathbf{( T Y R )}$ & ${ }^{\mathrm{f}}(\mathbf{S K R})$ \\
\hline$\alpha$-BHC & $4.0 \times 10^{3} \pm 45.0$ & $5.0 \times 10^{3} \pm 14.0$ & $4.2 \times 10^{3} \pm 11.9$ & $2.8 \times 10^{3} \pm 14.3$ \\
$\mathrm{HCB}$ & $2.0 \times 10^{3} \pm 20.0$ & $4.0 \times 10^{3} \pm 7.5$ & $2.5 \times 10^{3} \pm 16.0$ & $12.0 \times 10^{3} \pm 6.7$ \\
$\beta$-BHC & $24.0 \times 10^{3} \pm 2.1$ & $3.0 \times 10^{3} \pm 13.3$ & $2.0 \times 10^{3} \pm 20.0$ & $9.0 \times 10^{3} \pm 14.4$ \\
$\delta$-BHC & $5.0 \times 10^{3} \pm 16.0$ & Trace & $2.1 \times 10^{3} \pm 66.7$ & Trace \\
Heptachlor & $2.0 \times 10^{3} \pm 35.0$ & Trace & $2.0 \times 10^{3} \pm 15.0$ & Trace \\
Aldrin & Trace & $2.1 \times 10^{3} \pm 28.6$ & Trace & Trace \\
-Chlordane & Trace & $3.4 \times 10^{3} \pm 14.7$ & Trace & Trace \\
2,4'-DDE & $5.0 \times 10^{3} \pm 8.0$ & Trace & $3.5 \times 10^{3} \pm 22.9$ & $1.2 \times 10^{3} \pm 66.7$ \\
Endosulphan I & Trace & $3.0 \times 10^{3} \pm 6.7$ & $3.0 \times 10^{3} \pm 40.0$ & Trace \\
Dieldrin & Trace & $2.0 \times 10^{3} \pm 35.0$ & Trace & Trace \\
2,4'-DDD & $8.0 \times 10^{3} \pm 3.8$ & $5.0 \times 10^{3} \pm 16.0$ & Trace & Trace \\
Endrin & Trace & Trace & $2.0 \times 10^{3} \pm 35.0$ & Trace \\
4,4'-DDD & Trace & $2.0 \times 10^{3} \pm 25.0$ & Trace & Trace \\
2,4'-DDT & $3.0 \times 10^{3} \pm 6.7$ & Trace & Trace & Trace \\
4,4'-DDT & $8.0 \times 10^{3} \pm 15.0$ & Trace & Trace & $2.5 \times 10^{3} \pm 52.0$ \\
\hline
\end{tabular}

${ }^{\mathrm{a}}$ Mean of triplicate analyses, ${ }^{\mathrm{b}}$ Buffalo River, ${ }^{\mathrm{c}}$ Sandile Dam, ${ }^{\mathrm{d}}$ Keiskamma River, ${ }^{\mathrm{e}}$ Tyume River

$\mathrm{CV}=$ Coefficient of variation
DOONG R and LEE C (1999) Determination of organochlorine pesticide residues using solid-phase extraction cleanup cartridges. Analyst 124 1287-1289.

DOROTHEA FKR and MUIR DCG (1991). Sources of Chlorpyrifos and Dacthal to small Canadian Prairie watershed. Environ. Sci. 


\begin{tabular}{|c|c|c|c|c|}
\hline \multicolumn{5}{|c|}{$\begin{array}{c}\text { TABLE11 } \\
\text { aOrganochlorine pesticide levels }(\mathrm{ng} / \mathrm{kg} \pm \mathrm{CV}) \text { in sediment samples }\end{array}$} \\
\hline $\begin{array}{l}\text { Sampling } \\
\text { date }\end{array}$ & $26 / 04 / 02$ & $26 / 04 / 02$ & $26 / 04 / 02$ & $26 / 04 / 02$ \\
\hline OCPs & ${ }^{b}(B R)$ & ${ }^{d}(K R)$ & e(TYR) & ${ }^{f}$ (SKR) \\
\hline $\begin{array}{l}\alpha \text {-BHC } \\
\text { HCB } \\
\beta \text {-BHC } \\
\delta \text {-BHC } \\
\text { Heptachlor } \\
\text { Aldrin } \\
\gamma \text {-Chlordane } \\
\text { 2,4'-DDE } \\
\text { Endosulfan } \\
\text { Dieldrin } \\
\text { 2,4'-DDD } \\
\text { Endrin } \\
\text { 4,4'-DDD } \\
2,4^{\prime} \text {-DDT } \\
4,4^{\prime}-\text {-DDT }\end{array}$ & $\begin{array}{c}3.4 \times 10^{3} \pm 23.5 \\
\text { Trace } \\
6.0 \times 10^{3} \pm 8.3 \\
4.5 \times 10^{3} \pm 28.9 \\
\text { Trace } \\
\text { Trace } \\
\text { Trace } \\
3.0 \times 10^{3} \pm 3.3 \\
\text { Trace } \\
\text { Trace } \\
4.0 \times 10^{3} \pm 7.5 \\
2.0 \times 10^{3} \pm 15.0 \\
\text { Trace } \\
\text { Trace } \\
\text { Trace }\end{array}$ & $\begin{array}{c}3.0 \times 10^{3} \pm 6.7 \\
2.8 \times 10^{3} \pm 53.6 \\
5.0 \times 10^{3} \pm 10.0 \\
1.9 \times 10^{3} \pm 15.8 \\
\text { Trace } \\
2.0 \times 10^{3} \pm 20.0 \\
\text { Trace } \\
3.5 \times 10^{3} \pm 28.6 \\
\text { Trace } \\
\text { Trace } \\
6.0 \times 10^{3} \pm 5.0 \\
\text { Trace } \\
4.0 \times 10^{3} \pm 12.5 \\
\text { Trace } \\
3.0 \times 10^{3} \pm 13.3\end{array}$ & $\begin{array}{c}2.0 \times 10^{3} \pm 35.0 \\
5.0 \times 10^{3} \pm 6.0 \\
9.0 \times 10^{3} \pm 15.6 \\
3.0 \times 10^{3} \pm 26.7 \\
2.0 \times 10^{3} \pm 20.0 \\
\text { Trace } \\
\text { Trace } \\
5.0 \times 10^{3} \pm 30.0 \\
\text { Trace } \\
\text { Trace } \\
\text { Trace } \\
\text { Trace } \\
\text { Trace } \\
\text { Trace } \\
5.0 \times 10^{3} \pm 8.0\end{array}$ & $\begin{array}{c}\text { Trace } \\
5.4 \times 10^{3} \pm 3.7 \\
3.0 \times 10^{3} \pm 26.7 \\
\text { Trace } \\
5.0 \times 10^{3} \pm 8.0 \\
1.2 \times 10^{3} \pm 25.0 \\
\text { Trace } \\
\text { Trace } \\
\text { Trace } \\
1.0 \times 10^{3} \pm 30.0 \\
8.0 \times 10^{3} \pm 21.3 \\
\text { Trace } \\
\text { Trace } \\
\text { Trace } \\
\text { Trace }\end{array}$ \\
\hline \multicolumn{5}{|c|}{$\begin{array}{l}\text { a'Mean of triplicate analyses, }{ }^{\mathrm{b}} \text { Buffalo River, }{ }^{\mathrm{c}} \text { Sandile Dam, }{ }^{\mathrm{d}} \text { Keiskamma River, }{ }^{\mathrm{e}} \text { Tyume River } \\
\text { and }{ }_{\mathrm{f}}^{\mathrm{f}} \text { wartkops River } \\
\mathrm{CV}=\text { Coefficient of variation } \\
\text { Trace }=<\text { Detection limit }\end{array}$} \\
\hline
\end{tabular}

LONDON L, DALVIE MA, CAIRNCROSS E and SOLOMON A (2000) The Quality of Surface and Groundwater in the Rural Western Cape with Regard to Pesticides. Water Research Commission Report No. 795/1/00.

MILLER JC and MILLER JN (1998) Statistic for Analytical Chemistry (2nd edn.), Chapter 4. Ellis Horword, Chichester.

NAUDE Y, DE BEER WHJ, JOOSTE $S$, VAN DER MERWE L and VAN RENSBURG SJ (1998) Comparison of supercritical fluid extraction and Soxhlet extraction for the determination of DDT, DDD and DDE in sediment. Water SA 24 (3) $205-214$.

OKONKWO JO, KAMPITA L and CHINGAKULE DD (1999) Organochlorine insecticide residues in human milk: A study of lactating mothers in Siphofaneni, Swaziland. Bull. Environ. Contam. Toxicol. 63 243-247.

POWELL MW (1995) Development of a binary solid-phase extraction cartridges for use in screening water samples for organic pollutants. J. Chromatogr. A 697 101-105.

SAFE S (2001) Hydroxylated poly-

Technol. 33 3317-3323.

DWAF (1996) South African Water Quality Guidelines (Volume 7) Aquatic Ecosystems (1st edn.). Department of Water Affairs and Forestry, Pretoria.

EUROPEAN COMMUNITY (1980) Council Directive of 15th July 1980 relating to the quality of water intended for human consumption. 80/778/EEC. Off. J. Eur. Communities No L 229/11, 30/8/ 80, Buessells

FERNANDEZ-ALBA AR, AGUERA A, CONTRERAS M, PNUELA G, FERRER I and BARCELO D (1998) Comparison of various sample handling and analytical procedures for the monitoring of pesticides and metabolites in ground waters. J. Chromatogr. A $\mathbf{8 2 3}$ 35-47.

GROBLER DF (1994) A note on PCBs and chlorinated hydrocarbon pesticide residues in water, fish and sediment from Olifants River, Eastern Transvaal, South Africa. Water SA 20 (3) 187-194.

HEATH RG and CLAESSEN M (1999) An Overview of the Pesticide and Metal Levels Present in Populations of the Larger Indigenous Fish Species of Selected South African Rivers. Water Research Commission Report No. 428/1/99.

HERNANDEZ F, MORELL I, BETTRAN J and LOPEZ FJ (1993) Solid-phase extraction of pesticide residues from ground water: comparison between extraction cartridges and extraction discs. Anal. Chim. Acta 283 297-303.

HILEMAN E (1994) Environmental estrogens linked to reproductive abnormalities, cancer. $C$ and $E N, 31$ January, 19-23.

IWATA H, TANABE S, SAKAI N and NISHIMURA A (1994) Geographical distribution of persistent organochlorines in air, water and sediments from Asia and Oceania, and their implication for global distribution from lower latitudes. Environ. Pollut. 85 1533.

KEICE WR, STONE RC, LAW SC, EARL-GRAY L, KEMPPAINEN JA and WILSON EM (1995) Persistent DDT metabolite p,p DDE is a potent androgen receptor antagonist. Nature 375 581585 . chlorinated biphenyls (PCBs) and organochlorine pesticides as potential endocrine disruptors. In: Metzler M (ed.) The Handbook of Environmental Chemistry Vol. 3, Part L Endocrine Disruptors, Springer-Verlag, Berlin, Heidelberg. 155-167.

SNYDER JL, GROB RL, MACNALLY ME and OOSTDYK TS (1992) Comparison of supercritical fluid extraction with classical sonication and soxhlet extractions for selective pesticides. Anal. Chem. 64 1940-1946.

SOTO AM, CHUNG KL and SONNENSHEIN C (1994) The pesticide endosulfan, toxaphene and dieldrin have estrogenic effects on human estrogen sensitive cells. Environ. Health Perspect. 102 380 .

TAN GH (1992) Comparison of solvent extraction and solid-phase extraction for the determination of organochlorine pesticide residues in Water. Analyst $\mathbf{1 1 7} 1129$.

TANABE S, IWATA H and TATSUKAWA R (1994) Global contamination by persistent organochlorines and their ecotoxicological impact on marine mammals. Sci. Total. Environ. 154 163-177.

USEPA (US ENVIRONMENTAL PROTECTION AGENCY) (1990) Test Methods For Evaluating Solid Waste (3rd edn.), EPA SW-846, Method 3540. US Government Printing office, Washington DC.

USEPA (US ENVIRONMENTAL PROTECTION AGENCY) (1975) DDT: A Review of Scientific and Economic Aspects of the Decision to Ban its Use as a Pesticide. Washington DC.

USEPA (US ENVIRONMENTAL PROTECTION AGENCY) (1984) Test Method 608, Organochlorine Pesticides and PCBs. Environmental Monitoring System Laboratory, Cincinnati, OH, USA.

VAN DYK LP, WIESE IH and MULLEN JEC (1982) Management and determination of pesticide residues in South Africa. Residue Rev. 82 38-124.

WEAVER JMC (1993) A Preliminary Survey of Pesticide Levels in Groundwater from a Selected Area of Intensive Agriculture in the Western Cape. Water Research Commission Report No. 268/1/ 93. 